\title{
THE LARVAL DEVELOPMENT OF OPHELIA BICORNIS SAVIGNY
}

\author{
By Douglas P. Wilson, M.Sc., F.R.P.S. \\ Zoologist at the Plymouth Laboratory
}

(Text-figs. I, 2)

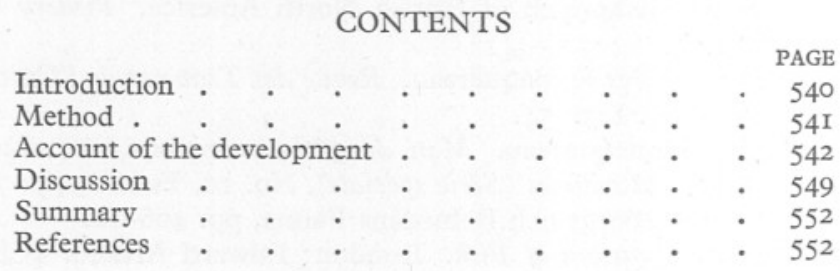

INTRODUCTION

The development of the Opheliidae has hitherto been unknown. Eggs and sperm have previously been described, but the larvae have not. The most recent attempt to study the development was made by Brown (1938) at Millport, using the small species Ophelia cluthensis McGuire, which is abundant in the sand at a certain level in Kames Bay. He described the eggs and sperm, and obtained cleavage as far as the 4-cell stage. McGuire (1935) had previously also observed cell division up to the 4-cell stage in the same species. Many years previously Bullot (1904) did experiments on artificial parthenogenesis in an Ophelia and obtained swimming larvae, but did not figure or describe them in detail. Benham (1896), in a text-book, stated that the eggs of Ophelia are enclosed in a jelly, but it is not clear whence this statement derives.

The Opheliidae are a family of small worms, most of them burrowing in sand or mud. The distribution of the various species seems to be rather markedly localized and most species appear to inhabit only a fairly narrow range in grade of bottom soil. It seemed likely that the development might be of special interest, especially the settling reactions of the larvae. This has, on the whole, proved to be true. In this present paper the larvae are described; the experiments on settling reactions will be discussed separately.

I am glad to have this opportunity of thanking $\mathrm{Mr} \mathrm{N}$. A. Holme of Exmouth, who drew my attention to the possibility of collecting $O$. bicornis Savigny on the sand banks at the mouth of the Exe estuary. The species had been found there many years earlier by Allen \& Todd (1902), but has not attracted particular attention in that locality since. Mr Holme on several occasions specially collected worms for me and forwarded them to Plymouth. At other times I collected them there myself. 


\section{METHOD}

O. bicornis Savigny lives in the loose clean sand of the Bullhill Bank and of the Polesands at the mouth of the Exe estuary. I myself have collected them only on the Bullhill Bank, but $\mathrm{Mr}$ Holme has also visited the Polesands and found them there, also in lesser abundance in other parts of the estuary. He will subsequently be publishing an account of the fauna of the Exe estuary, and will deal with their recent distribution in detail. Here it is sufficient to say that they are most abundant about the half-tide level, which approximately coincides with the top of the Bullhill Bank.

The sand in which they live is thus uncovered for several hours each tide. They inhabit the top few inches and are easily turned up with a spade or a trowel, and can even be got by using the fingers alone, drawing them through the sand. The adult worms are a little over an inch long; mature males are white or pale cream, mature females a deep metallic green. Immature and spawned worms are pinkish. All have a beautiful iridescent sheen. In collecting they were put into large jars with quantities of sand, and in the laboratory were kept under sea-water circulation in bowls with plenty of their natural sand to burrow in. Some rough experiments indicated that they survive better when the water is drained away for several hours each day to simulate the tides of their normal'environment. They could be kept up to a fortnight or three weeks, but the best fertilizations were made the day they were collected, or within a few days afterwards.

Artificial fertilizations were made by slitting open the worms, care being taken to avoid contamination with much blood. Several times, however, worms spawned naturally in the bowls and larvae from naturally spawned and fertilized eggs were found to be on the whole more virile than those from artificial fertilizations. Worms shedding eggs or sperm protruded the head and anterior segments from the sand; sometimes as much as half the body was exposed, particularly by the females; the males might show only the head and first few segments. The eggs and sperms issued from out of the hole from which the front end of the worm protruded; it was not possible to see them coming out of the body of the worm. The eggs and sperm were often ejected in 'puffs' caused by a sudden contraction of the worm into its hole. When worms in the act of spawning were removed in a dish to a microscope stage the spawning ceased and did not again start. After spawning, the hole of a female would often be surrounded by eggs loosely piled around its mouth; they were not adherent to one another; in nature the eggs would be swept away by the tidal current.

Developing eggs were kept in finger bowls, no more than sufficient to cover the bottom in a single layer being put into any one bowl. As soon as a goodly number of larvae had swum to the surface they were decanted off into a clean bowl and there reared. No food was needed, but the bowls were covered with 
sheets of glass and tissue paper to keep out dust and excess light. Bowls placed near the sea-water circulation remained fairly cool in hot weather, with benefit to the larvae. At about the time of metamorphosis a little food in the form of small autotrophic flagellates and the diatom Nitzschia was provided.

Larvae were examined and drawn alive, scale being obtained by the use of a squared-net micrometer in the eyepiece, the preliminary drawing being made on squared paper. Bristles were drawn with a camera lucida.

\section{AcCount of the Development}

Ripe eggs are dark green or greenish brown in colour. When freshly obtained from the female by slitting the body wall they are generally oval plates (Fig. I $a$ ), about $\mathrm{I} 50 \mu$ long by $\mathrm{I} 30 \mu$ broad, with a clear germinal vesicle near the centre. When seen in side view (Fig. I $b$ ) there is a definite bulge in the region of the nucleus. Sometimes a nucleolus is present, sometimes it has already disappeared. The cytoplasm is thinned out at one end, giving a clearer region when viewed with transmitted light. The rim round this region is, however, thicker. The egg is closely invested in a well-defined membrane outside which there is a completely transparent and invisible jelly, several microns thick, which makes it impossible to push one egg into visible contact with another.

If the eggs are not fertilized, there is no change in their appearance. They can remain in this condition for many hours (overnight) and still be fertilizable, though they seem to give healthier larvae if fertilized immediately.

Eggs spawned naturally and examined at once have also been found to correspond closely with this condition. Usually, however, such eggs are fertilized at once by males shedding sperm in the same bowl, and quickly proceed to develop.

From a female which had been interrupted in her spawning I have obtained, by slitting the body wall (a few hours later), eggs which were not quite the same. They were oval disks with a germinal vesicle and a bulge (when viewed laterally) in the region of the nucleus, but there was no specially thinned-out area at one end, and one pole was flattened as though for the reception of the sperm. Some of these eggs were kept for some time, but underwent no further change; others were fertilized and proceeded to develop, but on the whole did not give such healthy larvae as eggs of the other sort.

Some other variants of egg shape have been noted, so that at the moment it is not quite certain which should be regarded as the normal recently spawned but unfertilized egg.

On fertilization the egg rounds up, becoming spherical, of smaller diameter (about $95 \mu$ ) than that of the disk-shaped unfertilized egg and more opaque. The egg-membrane rises off the surface of the egg in a crumpled manner (Fig. I, $c$ ) and at the same time the invisible jelly-layer outside swells up. This is revealed by the excess sperms caught in it to form a halo around the egg, 
and by the greater distance eggs are kept apart from one another when attempts are made to push them into contact. The thickness of this jelly is about equal to the diameter of the egg itself.

Whilst the eggs are rounding up, the germinal vesicle disappears and polar bodies are soon given off; they are clearly visible under the egg membranes. This is followed by the first division stages.

In 24 hours or less, according to the temperature, larvae swim actively up to the surface and gather in swarms round the side of the bowl. They are not phototropic. They are almost spherical (Fig. I, $d$ ), rather opaque, and the same greenish brown colour as the eggs. Cell limits are fairly distinct, the cells being relatively large and densely granular. The central mass of the developing gut is rather more opaque and darker than the cells forming the body wall. The blastocoel is almost entirely occluded. A stomodaeal invagination is present. The whole is enclosed in the egg- or fertilization-membrane through which the cilia project. There is a long apical tuft, and a prototroch forms a complete band round the equator. The individual prototrochal cells can be traced fairly clearly - there is a double row, the cilia of the posterior row being a little shorter than those of the anterior. There is no telotroch. The larva swims forward in the direction of the apical tuft, mainly on a horizontal axis rotating as it goes.

As growth proceeds the larva elongates, the widest region of the body being at the prototroch. The apical tuft is large, the cilia varying in length, the longest in the middle. The prototroch is a broad uninterrupted band, immediately behind it ventrally is the developing stomodaeum. A telotroch of relatively short weak cilia soon appears (Fig. I, $e$ ); it is interrupted ventrally and dorsally by median gaps. Some patches of neurotrochal cilia appear and there is a long very thin cilium at the extreme posterior end. Granular greenish patches (chromatophores) form on the head in a transverse row immediately behind the prototroch, and a few smaller ones just in front of the telotroch.

With further elongation the first trunk segments become discernible through the segmental arrangement of additional chromatophores on the trunk (Fig. $\mathrm{I}, f$ ). Chromatophores also appear on the pygidium. On about the third day a granular reddish brown eyespot develops on the right side. The larval cuticle thickens over the head. It can be seen that the prototroch consists of three or four moderately distinct transverse bands of cilia placed very close together. The cells of the prototroch are more opaque than are those of the rest of the body wall-a feature that persists as long as the prototroch is present. The tissues generally are very granular and rather opaque, especially gut tissues not indicated in the drawing. The neurotroch, consisting of several patches of short cilia, becomes more strongly marked; it ends posteriorly in the mid-ventral gap in the telotroch. The anus is already formed. As further structures differentiate (Fig. I, $g, h, i$ ), the diameter of the prototroch shortens, 
the larva acquiring a more elongate appearance without any real gain in length. Segmental grooves appear, and parapodial lobes arise as small swellings on what will be the first two setigers. The first bristles soon protrude just dorsal to these lobes. The anus opens immediately behind the dorsal gap of the telotroch, and first one and then two pairs of papillae appear at the extreme posterior end of the body. The ventral pair of these is larger than the dorsal. There are now two eyespots and sometimes a third on the right side. The eyespots are cup-shaped, the opening of the cup being directed ventrally and laterally.

The larva can now wriggle violently, indicating the development of trunk musculature. The larva is a little more transparent than previously, the prototroch being the most opaque area. It should be noted that the line drawings give but a poor representation of the texture of the tissues. The gut is probably open at both ends, but it is uncertain whether the larva is feeding or not. The gut is still fairly granular. The mouth is well ciliated and there are short cilia on each side of it. The proboscis is developing.

The trunk now slowly elongates (Fig. $\mathrm{I}, j$ ) whilst the diameter of the prototroch remains more or less the same. The parapodial lobes of the third setiger appear (Fig. I, $j$ and Fig. 2, $a, b$ ), but not for some time does this segment acquire bristles (Fig. 2,c). The bristles of the first two setigers grow longer and are followed by others. First each dorsal bundle acquires a second bristle (Fig. I, $j$ ) and later the first setiger gets a ventral bristle on each side (Fig. 2, $a, b)$, followed later by the second setiger. By the time the third setiger has a single dorsal bristle on each side the first had often three dorsal and two ventral (Fig. 2,c) to each parapodium. There is variation in the rate at which the bristles of the first and second setiger appear in relation to the time of appearance of bristles on the third setiger. For a description of the bristles see p. 548 .

With further growth the apical tuft loses some of its cilia. The prototroch becomes a little narrower (Fig. 2, $a, b, c$ ); it can be seen to be composed of three or four rows of cells. The neurotroch consists of a series of patches of cilia, generally two per segment with considerable non-ciliated gaps between. The larvae swim steadily, sometimes swiftly, forward, rotating slowly, often in a more or less spiral path. Unless moving up or down they swim with the body horizontal, or nearly so.

When the third setiger bristles are seen the larvae are six to eight days old, though sometimes younger and sometimes older according to the temperature. It is at about this stage that metamorphosis first becomes possible, though, as will be shown later, it rarely takes place except in sand of a suitable character. At about this stage too there is a change in the behaviour of the larvae. Whereas during the first few days they had swum up towards the surface and had shown no reaction to light, they now move away from a light source and can be driven to and fro, up or down in the glass bowl by moving an electric lamp 
into appropriate positions. They gather on the side of the bowl away from the window. At this same stage they are also to a large extent positively geotropic. Thus, if a bowl of larvae be stirred so that they are evenly distributed throughout, and a light-tight cover be placed over the bowl for a few minutes, it will be found that the great majority of the larvae go to the bottom. In a bowl left in darkness all night, however, the majority were at the surface in the morning, these larvae immediately moved away from the light when they were uncovered and gathered about half-way down the bowl on the side away from the window. The cover was replaced for I 5 min. at the end of which period the larvae had gathered on the bottom of the bowl.

Negative phototropism and positive geotropism will in the sea lead metamorphosis-ripe larvae to the sea bottom. What happens to them there will be discussed in another paper; we are here concerned only with general details of the metamorphosis.

When ready to metamorphose Ophelia larvae readily cling to any solid object with which they may come into contact. The sides of a bowl, the walls of a pipette, and grains of sand are only some of the objects adhered to. They may show this habit as early as the fifth or sixth day. Attachment is effected primarily by the four anal papillae, aided often, especially in older larvae, by the parapodial lobes. Adhesion is effected by a secretion produced by glands at the bases of the papillae and of the lobes, and discharged by canals opening at pores on the tips of these protuberances. Parapodial lobes have one gland for each, but each anal papilla has several. At first, larvae can easily detach themselves and swim away, but after a few days they stick more firmly and this, combined with a loss of swimming strength due to a decrease in power of the prototroch with age, results in their being unable to get away. Thus they become stuck to the glass of a clean finger bowl, though they may be detached by squirting water from a pipette.

A larva attached by the anal papillae to the bottom of a glass dish stands upright with the prototroch beating strongly. It similarly stands upright on sand grains, unless it actually burrows into the sand and metamorphoses. This ability to cling strongly to sand grains must aid the larvae in settling on the current-swept sand banks in which they will live when adult. Such a mechanism seems to be needed in order that they may anchor themselves immediately contact is made with the bottom soil. A quick efficient attachment mechanism is a necessity for settling in regions swept by strong currents, and the anal papillae and parapodial lobes, with their associated glands, fulfil this need.

Larvae, after settling on the surface of the sand, make their way into it. If the sand be suitable, they may stay there, but they have been seen to come out and swim away. Often they remain on the surface of an unsuitable sand, attached to a grain by the anal papillae, the body upright, swaying, with the prototroch beating strongly. It has seemed as if they needed a current of water to launch them up and away from the bottom. 


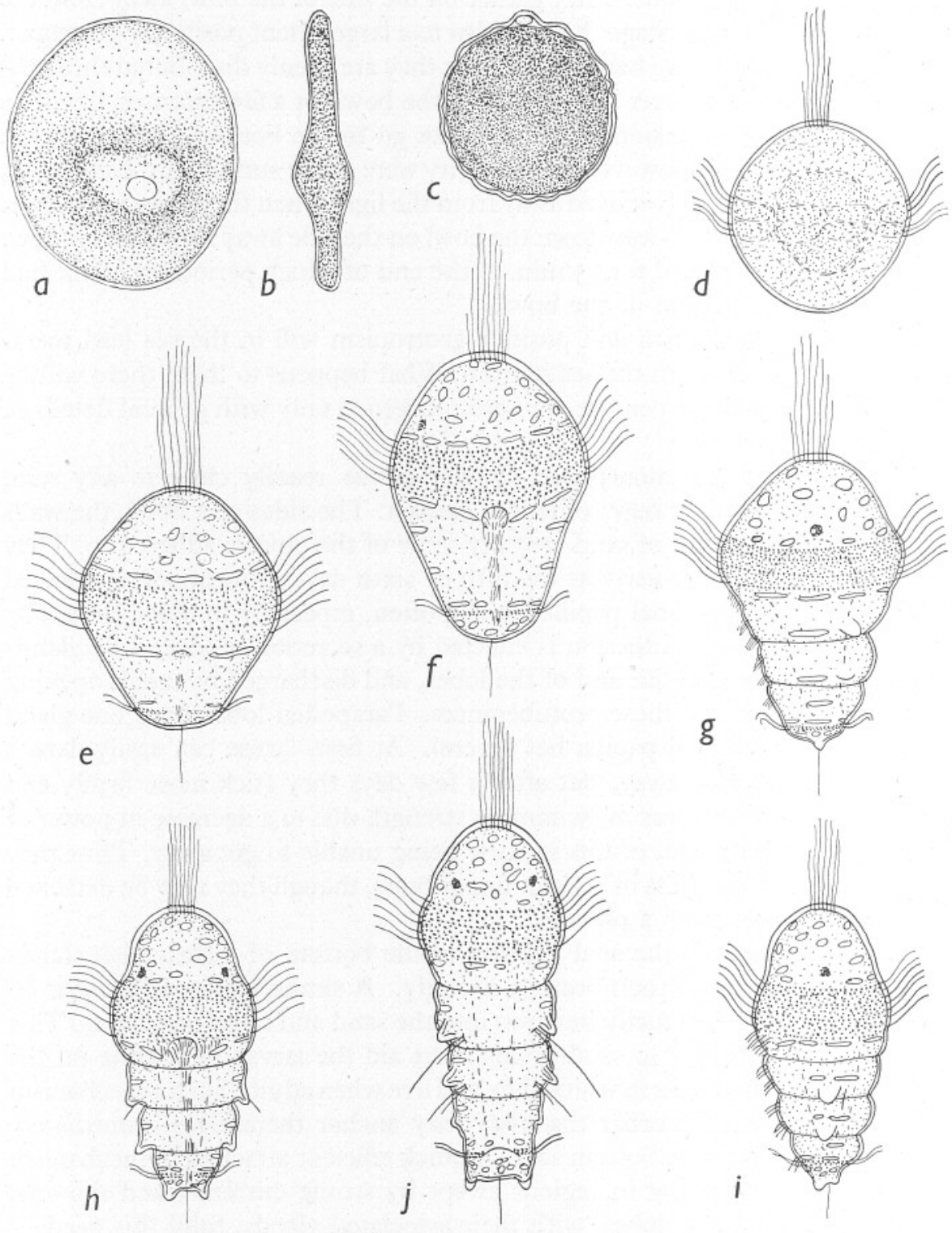

Fig. I. Eggs and larvae of Ophelia bicornis, $\times 225 . a$, unfertilized egg; $b$, the same in side view; $c$, fertilized egg with polar body; $d$, I-day-old larva; $e$, 2-day-old larva, ventral view; $f, 3$-day-old larva, ventral view; $g$, 4-day-old larva, view of left side; $h, i, 4$ to 5 -day-old larva, ventral view and view of left side; $j$, 5-day-old larva, dorsal view. 
In a suitable sand the larvae metamorphose. The apical cilia are lost, the prototroch, telotroch and neurotroch disappear and all power of swimming is
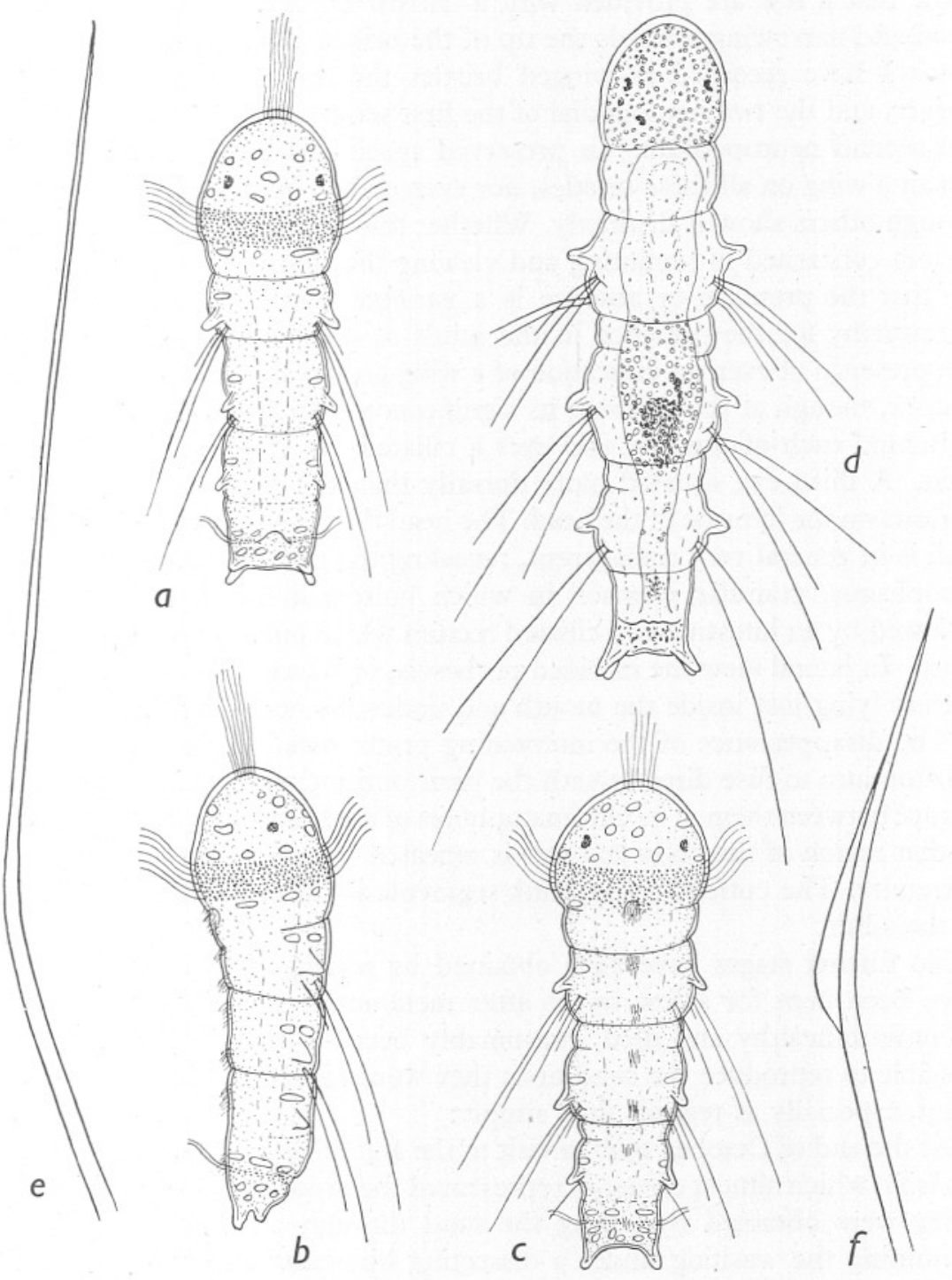

Fig. 2. Larvae of Ophelia bicornis, $\times 225$; bristles, $\times 1600$. $a, b, 7$-day-old larva, ventral view and view of left side; $c$, II-day-old larva, ventral view; $d$, young worm, after metamorphosis and I9 days old, dorsal view; $e$, capillary bristle; $f$, winged bristle.

lost. The body elongates and the worm (Fig. 2,d) crawls among the sand grains to which it can adhere strongly. The bristles grow rapidly, especially those of the third setiger which soon exceed in length the anterior ones. 
The bristles appear at first sight to be all fine smooth capillaries, often bent at a slight angle near the base (Fig. 2,e); more careful observations, however, show that a few are provided with a narrow bordering wing, widest at the bend and narrowing towards the tip of the bristle (Fig. 2, $f$ ). In living specimens I have recorded as winged bristles the third notopodial in the first setiger, and the two neuropodial of the first setiger, also the shorter ventral of the second neuropodium. In preserved specimens I have not been able to detect a wing on all these bristles, nor even on any bristles of some specimens, though others show it distinctly. Whether this is due to preservation and the factors concerned in mounting and viewing the specimen is not clear, it may be that the presence or absence is a variable feature. The Opheliidae are noteworthy for the presence in the adult of capillary bristles only, so that the presence of even an indication of a wing on larval bristles is an interesting feature, though at the moment its significance is far from clear.

Behind each of the first two eyes a ciliated pit, the nuchal organ, can be seen. A third eye situated more dorsally than the others and behind them, appears on the left side of the head. The head tissues are granular, but the body wall is in general very transparent, revealing the gut. The latter has a ciliated oesophagus, granular stomach in which bottom-living diatoms are visible, followed by an intestine and ciliated rectum which opens at a dorsally situated anus. In lateral view the infolded proboscis; or buccal mass, is a conspicuous feature lying just inside the mouth and under the oesophagus.

The disappearance of the intervening prototrochal tissues has allowed the prostomium to fuse directly with the peristomium, there being a well-marked groove between them. The chromatophores of the head give a darker appearance to that region of the body and this is repeated to some extent at the posterior extremity. The cuticle of the trunk segments is transversely wrinkled as it is in the adult.

No further stages have been obtained by rearing, although young worms have been kept for a few weeks after metamorphosis. They have gradually become unhealthy and died, presumably because in dishes it has not been possible to reproduce the conditions they would find in their natural environment, especially as regards food supply.

At the end of October 1947, a visit to the Bullhill Bank produced two young Ophelia, which almost certainly represented the brood of the previous summer. They were obtained by sifting the sand through a fine meshed sieve and examining the washing under a dissecting binocular in the laboratory. The smaller specimen was about $5 \mathrm{~mm}$. long (fixed) and had twenty-five setigers; the gut contained about ten relatively large sand grains. The larger specimen was about $7 \mathrm{~mm}$. long (fixed) and had twenty-eight setigers; there were a few small sand grains in the gut. The general appearance of these specimens resembled fairly closely that of the adult, but there were differences due to incomplete development. Thus the smaller specimen had only two pairs of 
branchiae, definitely recognizable as such, though the larger had fifteen, the adult number. The first and last branchiae in both specimens were very small. An interesting feature was that whilst in the adult the anterior pair of branchiae occur on the eleventh setiger the anterior pair in the smaller specimen was on the twelfth setiger and was smaller than the succeeding pair. However, there was some slight indication of the presence of branchial rudiments on the eleventh setiger suggesting that these grow at a later stage. This is in agreement with the condition of the larger specimen which bore small but distinct branchial rudiments on the eleventh setiger, whilst the second pair on the twelfth setiger were considerably smaller than on the thirteenth and immediately succeeding setigers. In the adult the first few pairs of branchiae are rather smaller than those succeeding them, but it is, nevertheless, evident that the order of appearance of the branchiae in Ophelia is worthy of some attention when more material is available.

\section{Discussion}

Slowly the gaps in our knowledge of polychaete development are being filled, but the work that remains to be done before anything like a reasonably complete picture of polychaete embryology can be attained is very great indeed. There are still whole families for which data are either non-existent or of the most fragmentary kind. The position has changed little since my assessment of it twelve years ago (Wilson, I936), and one has only to read Thorson's recent (I946) magnificent and painstaking compilation of old and new notes on the planktonic larvae of Danish polychaetes to be forcibly reminded of this unsatisfactory state of affairs. Thorson adds much that is new and he brilliantly summarizes many aspects, not least that of the confusion which still remains to be cleared up. 'In spite of the rather copious literature the larval Polychaetes are still poorly known' (p. 34). As he points out, the development of several common species is quite unknown.

That this should be so is not always the result of lack of effort directed to their elucidation. Several families have defied long-sustained efforts to penetrate their secrets, not least among them being the important Maldanidae and Ampharetidae, and to only a slightly lesser extent the Nephthydidae and Glyceridae. More than one worker has spent much time attempting to investigate the embryology of species belonging to these groups, with very little to show for it. From time to time, however, a species of polychaete is reared for the first time and should it happen to belong, as in the present instance, to a family whose development was previously not known, its development, even though it be of a simple straightforward type, cannot fail to be a valued addition to previous knowledge.

The development of Ophelia is of this simple straightforward type; its larva differs only in relatively minor details from that common to several other families of polychaetes (Syllidae, Eunicidae, Cirratulidae, Capitellidae, Areni- 
colidae, Terebellidae, Sabellidae). The common type is of moderate size, often rather yolky though not exceedingly so and, apart from the usual ciliated girdles (prototroch and telotroch) and ciliary tufts (apical and anal), shows no great structural specializations for swimming. Relatively few segments have been formed by the time the prototroch and telotroch are lost, that is, when metamorphosis can be said to have taken place. These segments, if setigerous, bear, as a rule, developing parapodia each with a few bristles of no great length. Slight variations of this pattern occur from family to family; sometimes a whole organ, such as the telotroch, may be reduced or absent. Some families have more yolk than others and, naturally enough, there is variation within the family, though often the development of so very few species within a family is known that on this latter point the statement rests on a little more than conjecture. The pelagic life of this typical simple form of larva is frequently, though not always, relatively short; that is, it does not extend over more than a few days (except when the post-larva is also pelagic, as in some terebellids). Food is often not taken until settlement has been effected.

In rather marked contrast to the foregoing are the larvae of some of the other polychaete families, larvae which show pronounced structural features which appear to be adaptations to a prolonged and active existence in the plankton. There may, for instance, be supernumerary rings of strong cilia (as in Spionidae and Chaetopteridae), sometimes on many segments, and there are frequently very long provisional bristles (especially well seen in Spionidae, Magelonidae, Oweniidae and Sabellariidae) which, in addition to their protective, and possibly suspensory functions, may with the aid of specialized cilia give rigidity to the body when swimming (in some, at any rate, of the Spionidae and Sabellariidae). The prototroch may be enlarged as it is in the Amphictenidae, Sabellariidae, Magelonidae and, above all, in the Oweniidae where it is sometimes looped and twisted in the manner of an echinoderm larva. A relatively spacious blastocoel is sometimes associated with an enlarged prototroch; this is especially well seen in the Oweniidae and it is a feature of the large trochosphere of Polygordius, and to a lesser extent of the smaller trochospheres of the Serpulidae, and perhaps one or two other families as well.

The larvae of the Aphroditidae, Phyllodocidae, Nereidae, Nephthydidae and maybe others, fall somewhere between these extremes. Thus the larvae of the polynoids have for the first part of their pelagic life a fairly well pronounced prototroch and long and numerous bristles, but their development is in many ways specialized along lines peculiar to the family. In the Nereidae there is much variation but the larvae of the family are at best feeble swimmers; some do not swim at all. Apart from their rather long bristles they resemble more nearly the simple type of larva than does the larva of the polynoids. The mode of their development fits them for early crawling rather than for prolonged swimming. The Nephthydidae and Phyllodocidae, however, contain a number 
of species with long planktonic lives, their larvae reaching a considerable size with numerous segments before settling. They do not possess specially long bristles and their prototrochs and telotrochs are not unduly large, though it is possible that they are specially strongly ciliated. More information is needed on these points before any definite conclusions as to the manner of their adaptation can be reached.

The development of Ophelia and other families with a simple larva is less specialized than the developments of the more spectacular types. Whether this is primitive or is a secondary simplification is not clear; the polychaetes are a very old group in geological time and many changes must have taken place in their ontogeny during the long period of their evolution; such points therefore are not easy to decide. It does, however, seem reasonable to suppose that long provisional bristles, enlarged prototrochs, swollen blastocoels and the other features of the more structurally complex pelagic types are adaptations which have been evolved over a very long period of time. In each family possessing one or more such structural features a somewhat standard pattern has been followed, common to the family but differing from that of other families. It is possible, in theory, to imagine that all these modifications have been produced by the exaggeration or suppression of the structures present in an ancestral simple type of larva not greatly different from that of Ophelia. This latter type of larva should be regarded as the typical polychaete larva and it is unfortunate that in the text-books the rather specialized Polygordius larva and the trochosphere of the serpulids should, apparently largely by the accident of having been among the first to be described in detail, have been taken as standard types. As long ago as I9II Shearer pointed out the unsuitability of the serpulid larva for a text-book type and more recently Segrove (I94I), working on the same family, has concurred in this. A larva such as that of Ophelia or of Notomastus has far more claim for consideration for this purpose, though there may be others, as yet undescribed, that would be even more suitable.

The projection of the posterior bristles well behind the anal extremity in the newly metamorphosed young Ophelia is a feature of the young of the allied Polyophthalmus and of mature sexual individuals of the latter also. Good figures of this are given by Stolte (1937). In adult Ophelia the bristles of the posterior setigers are not so pronounced, though they are moderately long and numerous, they barely pass behind the extremities of the anal papillae. In Armandia the last setigers bear very long capillary bristles, although it appears that the anal tube is produced beyond their backward reach. The posterior bristles of Travisia and Ammotrypane are short and rather inconspicuous. If now the grade of the bottom soil in which these various genera be considered, there becomes apparent some slight correlation with grade, for, on the whole, the finer the soil the shorter the posterior bristles. Thus Ammotrypane and Travisia inhabit fine sand and mud, Ophelia sands of varying grade according 
to the species. Armandia is found in coarse loose sand (Fauvel, 1925, I927), Polyophthalmus among rocks and weeds (Southern, I9I4; Fauvel, I925). In the latter the bristles are specially well developed at the time of sexual maturity when the worm becomes pelagic at night. It may, therefore, be that the function of these bristles is in some way connected with the kind of bottom inhabited by the adult. What this function is can as yet scarcely be guessed, but if it be true that the length of the posterior bristles is functionally related to the grade of the soil then the relatively long bristles of the very young Ophelia are probably an expression of this relationship. For to the newly metamorphosed worm the sand in which it has settled is comparatively coarse, but with increasing stature becomes relatively finer. In the young, therefore, the bristles are longer in relation to the body size than they are in the adult.

\section{SUMMARY}

Fertilizations of Ophelia bicornis Savigny were made and the larvae reared. This is the first time the larval development of any member of the family Opheliidae has been described.

The trochosphere is small and somewhat yolky; it has a broad prototroch, a narrow telotroch, a strong apical tuft and a long anal cilium.

Annulation is accompanied by the appearance of parapodial lobes and bristles. When the first pair of bristles of the third setiger protrude the larva is ready to metamorphose. It has two, sometimes three eyes.

The larva in its later stages can adhere strongly to solid objects, such as sand grains, by a secretion from the four anal papillae and the parapodial lobes. This is interpreted as an adaptive aid to settlement on sand banks swept by strong currents.

At metamorphosis the larval external cilia are lost and the bristles rapidly elongate, especially those of the third setiger.

Some of the larval bristles are slightly winged. So far only capillary bristles have been known in the Opheliidae.

- It is pointed out that a development such as that of Ophelia is more typical of polychaetes as a whole than are the developments of certain species commonly used as text-book types.

\section{REFERENCES}

Allen, E. J. \& Todd, R. A., I902. The fauna of the Exe estuary. Fourn. Mar. Biol. Assoc., Vol. vi, pp. 295-335.

Benham, W. B., I896. Archiannelida, Polychaeta and Myzostomaria. The Cambridge Natural History, Vol. II, London.

Brown, R. S., I938. The anatomy of the polychaete Ophelia cluthensis McGuire 1935. Proc. Roy. Soc. Edin., Vol. LvIII, pp. 135-60.

Bullot, G., I904. Artificial parthenogenesis and regular segmentation in an annelid (Ophelia). Arch. Entwickmech., Bd. 18, pp. 161-70. 
Fauvel, P., I925. Sur les ophéliens des côtes de France. Bull. Soc. Zool. France, T. L, pp. $77-88$.

- 1927. Polychètes sédentaires. Faune de France. I6. Paris.

MCGuIRE, I. P., I935. Note on a new species of polychaete (Ophelia cluthensis). Scot. Nat., 1935, pp. 45-6.

Segrove, F., I94I. The development of the serpulid Pomatoceros triqueter L. Quart. F. Micr. Sci., Vol. 82, pp. 467-540.

SHEARER, C., I9I I. On the development and structure of the trochophore of Hydroides uncinatus (Eupomatus). Quart. F. Micr. Sci., Vol. 56, pp. 543-90.

Southern, R., I914. Archiannelida and Polychaeta. Clare Island Survey. Proc. Roy. Irish Acad., Vol. xxxI, Section 2, Part 47, pp. 1-I60.

Stolte, H. A., I937. Gestaltung, Zeichnung und Organabbau unter dem Einfluss normaler und 'alternder' Gonaden bei Polyophthalmus pictus Duj. (Polychaeta). Zeit. Wiss. Zool., Bd. I50, pp. 107-54.

Thorson, G., 1946. Reproduction and larval development of Danish marine bottom invertebrates. Medd. Komm. Danmarks Fisk. Havund., Ser. Plankton, Bd. 4, pp. I-523.

WiLson, D. P., I936. The development of the sabellid Branchiomma vesiculosum. Quart. F. Micr. Sci., Vol. 78, pp. 543-603.

\section{ADDENDUM}

Just before going to press a paper ${ }^{1}$ has been received from Shiro Okuda giving for the first time an account of the development of an ampharetid worm. The development is of the simple straightforward type, the larva being of moderate size, somewhat yolky, and not differing greatly from that of Ophelia and similar types, especially in the earlier stages.

1 Okuda, S., I947. On an ampharetid worm, Schistocomus sovjecticus Annenkova, with some notes on its larval development. Fourn. Faculty Sci. Hokkaido Imp. Univ., Ser. VI, Vol. IX, pp. 32I-9. 